\title{
Innovations
}

\section{Doctors with borders: The White Helmets and radical political medicine}

\author{
Medical Humanities in the Middle East Conference \\ November 17-18, 2018 \\ Doha, Qatar
}

\section{Authors}

Saljooq M. Asif ${ }^{*}$; Soubhana Asif ${ }^{2}$

\section{Abstract}

Consisting of more than 3,000 civilians, the Syria Civil Defence (SCD) has gained international recognition for its humanitarian interventions in the Syrian Civil War. As first responders at the scenes of airstrikes, these volunteers provide emergency evacuation, urban search and rescue, firefighting, community engagement, and medical response in Syrian opposition-controlled areas. More popularly known as the White Helmets, the organization's prominent role in the Syrian crisis invites an exploration of the meaning of humanitarianism during warfare, particularly when compared to Western humanitarian efforts such as Médecins Sans Frontières (MSF) in the same region.
In A Dying Colonialism, physician-scholar Frantz Fanon examines the relationship between medical and colonial frameworks against the backdrop of the Algerian Revolution. Fanon draws a distinction between the invasive Western doctor and the native physician: whereas the former "always appears as a link in the colonialist network, as a spokesman for the occupying power,"1 the latter is a potential embodiment of decolonial resistance. Thus, the clinical encounter between the native population and the foreign doctor becomes a microcosm of colonial rule, one that is characterized by confrontation and distrust.

Raed Al-Saleh, director of the White Helmets, has stated that this issue of trust is at the core of humanitarian aid within the Syrian crisis. ${ }^{2}$ While international response to the conflict has been limited, the White Helmets are dedicated to restoring trust and goodwill in the Syrian
'Program in Narrative Medicine, Columbia University School of Professional Studies, New York, United States

2Medical Anthropology \& Cross-Cultural Practice Program, Boston University School of Medicine, Boston, United States

*Email: sma2205@columbia.edu

Saljooq M. Asif iD https://orcid.org/0000-0002-7431-7460

\section{Cite this article as:}

Asif SM, Asif S. Doctors with borders: The White Helmets and radical political medicine. In: Weber AS, Verjee MA, editors. Proceedings of the 1st International Conference on Medical Humanities in the Middle East [Internet]; 2018 Nov 17-18: Doha, Qatar: Innovations in Global Health Professions Education; 2019 March. p. 27-29. (Innovations in Global Health Professions Education; vol. 2019, spec. no.: 1). https://dx.doi.org/10.20421/ ighpe2019.01.09

This is an open access article distributed under the terms of the Creative Commons Attribution license CC BY 4.0, which permits unrestricted use, distribution and reproduction in any medium, provided the original work is properly cited. 
community, to rebuild the country into a "stable, prosperous and peace loving nation in which the social, economic and political aspirations of her people can be realised." ${ }^{3}$ By taking on this mission, the White Helmets become Fanon's native doctor, humanitarians who are fighting on the frontlines and directly embroiled in the conflict.

Although MSF has worked in Syria since 2009 and continues to provide significant humanitarian resources, their scope is limited in terms of vision and long-term change. ${ }^{4}$ Rather than dissolving boundaries as their name implies, MSF may be reifying geopolitical borders through its legitimization of the Syrian regime. Whereas the White Helmets avoid entering regime-controlled areas due to the threat of bodily harm, MSF refrains from entering these areas because they seek the explicit guarantee of safety and security from the Syrian regime. Indeed, in May 2018, MSF issued its first public appeal to the Syrian regime to reverse its seven-year ban on medical charity to no avail. ${ }^{5}$

By refusing to reckon with medicine's complicity in political oppression, MSF not only adopts the role of Fanon's Western doctor, but also practices what Miriam Ticktin labels "new humanitarianism," an ideology that is focused on caring rather than curing the root of the problem. ${ }^{6} \mathrm{New}$ humanitarianism is short-sighted in that, by avoiding political and social contexts enmeshed in current-day conflict, it provides immediate yet only temporary relief. In this way, MSF is working within a political framework without enacting long-lasting change that will benefit the local Syrian population.

Perhaps, then, medicine and humanitarianism must be reframed as inherently political. Physiciananthropologist Sam Dubal advocates for what he calls a "radical political medicine," one that recognizes that healthcare has historically been complicit in oppressive regimes and social injustice. ${ }^{7}$ Indeed, medicine has essentially been weaponized by the Syrian regime and Russian forces in the Syrian Civil War: hospitals and healthcare professionals are targeted for attacks precisely because of their life-saving efforts and the care they administer to people in need. ${ }^{8}$ Unlike MSF, which provides temporary solutions via new humanitarianism, the White Helmets may be practicing Dubal's radical political medicine.
The White Helmets look beyond saving immediate physical bodies or preventing emergencies-as native doctors, they are devoted to their people as well as their mission: the reconstruction of a socially just Syria.

The White Helmets' potential for radical political medicine, however, is severely undercut by its dependence on Western funding. The bestowal or withdrawal of support from Western states thus places the White Helmets in a precarious position that highlights the politicization of medicine amidst globalization. ${ }^{9}$ Perhaps Syria is now, or may have always been, entangled within a larger exosystem, a neo-colonialist framework that privileges Western agendas. With this in mind, the purpose of international humanitarian aid must be reevaluated while wrestling with the discomfort that perfection may never be attained in a "second-best world." 10

Conflicts of interest: None.

Funding sources: None.

\section{References}

1. Fanon F. A dying colonialism [L'An V, de la Révolution Algérienne]. Chevalier $\mathrm{H}$, translator. New York: Grove Press; 1965. Chapter 4, Medicine and Colonialism; p. 121-45.

2. Al-Saleh R. We're the White Helmets ordinary Syrians on a rescue mission. The Globe and Mail [Internet]. 2016 Dec 9 [updated 2017 Apr 11; cited 2018 Nov 21]; Opinion: [about 4 screens]. Available from: https://www. theglobeandmail.com/opinion/pulling-syriansout-of-the-rubble-and-giving-hope-to-asuffering-nation/article33268880/

3. Syria Civil Defence [Internet]. Aleppo, Syria: Syria Civil Defence; c2014-. About Us; c2014 [cited 2018 Nov 21]; [about 1 screen]. Available from: http://syriacivildefense.org/about-us

4. International Activity Report 2017 [Internet]. Geneva, Switzerland: Médecins Sans Frontières; 2017. Syria; 2017 [cited 2018 Nov 21]; [about 10 screens]. Available from: https://www.msf.org/international-activityreport-2017/syria 
5. Doctors Without Borders urges Syrian regime to lift 7-year access ban. The New Arab [Internet]. 2018 May 24 [cited 2018 Nov 21]. Available from: https://www.alaraby.co.uk/ english/news/2018/5/24/msf-urges-syrianregime-to-lift-7-year-access-ban

6. Ticktin Ml. Casualties of care: Immigration and the politics of humanitarianism in France. Berkeley: University of California Press; 2011. Chapter 2, Genealogies of care: The new humanitarianism; p. 60-86.

7. Dubal S. Being ethical in an unethical world [blog on the Internet]. [place unknown]: Sam Dubal. 2011-2012. Renouncing Paul Farmer: A desperate plea for radical political medicine; 2012 May 27 [cited 21 Nov 2018]; [about 8 screens]. Available from: http://samdubal. blogspot.com/2012/05/renouncing-paulfarmer-desperate-plea.html

8. Fouad FM, Sparrow A, Tarakji A, Alameddine $\mathrm{M}$, El-Jardali F, Coutts AP, et al. Health workers and the weaponisation of health care in Syria: A preliminary inquiry for The LancetAmerican University of Beirut Commission on Syria. Lancet. 2017 Dec 2;390(10111):2516-2526. doi:10.1016/s0140-6736(17)30741-9

9. Greenwood M. Trump administration releases funding for Syria's 'White Helmets.' Hill [Internet]. 2018 Jun 4 [cited 2018 Nov 21]; Policy: [about 4 screens]. Available from: https://thehill.com/policy/ international/392383-trump-administrationreleases-funding-for-syrias-white-helmets
10. Terry F. Condemned to repeat? The paradox of humanitarian action. Ithaca: Cornell University Press; 2002. Chapter 6, Humanitarian action in a second-best world; p. 216-45.

\section{About the authors}

Saljooq M. Asif is a Lecturer in the Program in Narrative Medicine at Columbia University School of Professional Studies. His work has appeared in U.S. Studies Online, Intima: A Journal of Narrative Medicine, Journal of Medical Humanities, Journal of Literary \& Cultural Disability Studies, and Literature and Medicine (in press).

Soubhana Asif is a master's student in the Medical Anthropology \& Cross-Cultural Practice Program at Boston University School of Medicine. Her scholarly interests include syndemics in regard to migrant health, and her thesis plans to explore the concept of aging and perception of elderhood in the urban Native American community. 